\title{
The Case for Revision of Routing
}

\author{
from W. L. S. Harrison
}

ON page 533 of the October 1970 issue of the Journal $(\mathbf{2 3}, 4)$, the following passage appears :

'At a recent meeting of the Safety of Navigation Committee of the Board of Trade, those present were advised by the Mercantile Marine Service Association that they had independently circulated a simple form of the present plan and the proposed reversal of routing to some 2300 Masters of their Association. Of the 500 replies received at that time, two-thirds supported the plan for reversal'.

In the view of the M.M.S.A. Council, the expression 'two-thirds' reflects an overstatement of the proportion of members of the Association who support the plan for reversal of the traffic flow in the Dover Strait. For the sake of strict accuracy, the following figures should be taken into account when assessing the results of this ballot: 574 forms were returned (about 25 per cent of those sent out) of whom 206 ( 36 per cent) were in favour of the Imco modifications suggestion and 368 (64 per cent) were in favour of the Trinity House (reversed flow) proposal. Taking only those members commanding ships of over $30 \mathrm{ft}$. draught and regularly using the Strait, however, 120 (40 per cent) favoured the Imco suggestion and 176 (60 per cent) the Trinity House proposal.

In the view of the M.M.S.A. Council, it was the expression of opinion of those Masters commanding ships of the greatest draught and regularly using the Strait which should be regarded as being most significant, and which reveals that members were almost equally divided on this issue.

\section{Collisions Between Very Large Ships}

\author{
P. C. H. Clissold
}

WE have not yet heard the full story of the Pacific Glory-Allegro collision and it may be jumping the gun to make any comment, but one thing seems to be clear about the handling of very large single-screw ships. Because of their unwieldiness an avoiding action must be initiated while still at a considerable distance from the threat, if it is to have any effect. This distance is beyond that at which the 